\title{
29th annual conference of the European Society for Biomaterials
}

Citation for published version (APA):

Habibovic, P., Hofmann, S., \& van den Beucken, J. (2020). 29th annual conference of the European Society for Biomaterials. Biomaterials Science, 8(1), 16-17. https://doi.org/10.1039/c9bm90066g

Document status and date:

Published: 01/01/2020

DOI:

10.1039/c9bm90066g

Document Version:

Publisher's PDF, also known as Version of record

Document license:

Taverne

Please check the document version of this publication:

- A submitted manuscript is the version of the article upon submission and before peer-review. There can be important differences between the submitted version and the official published version of record.

People interested in the research are advised to contact the author for the final version of the publication, or visit the DOI to the publisher's website.

- The final author version and the galley proof are versions of the publication after peer review.

- The final published version features the final layout of the paper including the volume, issue and page numbers.

Link to publication

\footnotetext{
General rights rights.

- You may freely distribute the URL identifying the publication in the public portal. please follow below link for the End User Agreement:

www.umlib.nl/taverne-license

Take down policy

If you believe that this document breaches copyright please contact us at:

repository@maastrichtuniversity.nl

providing details and we will investigate your claim.
}

Copyright and moral rights for the publications made accessible in the public portal are retained by the authors and/or other copyright owners and it is a condition of accessing publications that users recognise and abide by the legal requirements associated with these

- Users may download and print one copy of any publication from the public portal for the purpose of private study or research.

- You may not further distribute the material or use it for any profit-making activity or commercial gain

If the publication is distributed under the terms of Article $25 \mathrm{fa}$ of the Dutch Copyright Act, indicated by the "Taverne" license above, 


\section{Biomaterials Science}

\section{EDITORIAL}

View Article Online

View Journal I View Issue

\section{A) Check for updates}

Cite this: Biomater. Sci., 2020, 8, 16

DOI: $10.1039 / \mathrm{c} 9 \mathrm{bm} 90066 \mathrm{~g}$

rsc.li/biomaterials-science

\section{9th annual conference of the European Society for Biomaterials}

\author{
Pamela Habibovic, (D) *a Sandra Hofmann (D) ${ }^{b}$ and Jeroen van den Beucken (iD ${ }^{c}$
}

Annual meetings of the European Society for Biomaterials (ESB), the oldest and one of the largest societies in the field of materials for biomedical applications, are events that bring together academics, clinicians, and industrial researchers, to exchange advancements in the field and identify new opportunities. Themed 'Materials for Life', the 29th edition of the annual ESB conference was held in Maastricht, the Netherlands. It offered a chance for sharing knowledge, experiences and

${ }^{a}$ ESB2018 conference chair, MERLN Institute for Technology-Inspired Regenerative Medicine, Maastricht University, Maastricht, The Netherlands. E-mail:p.habibovic@maastrichtuniversity.nl ${ }^{b}$ ESB2018 organizing committee member, Orthopaedic Biomechanics group, Dept. Biomedical Engineering and Institute of Complex Molecular Systems, Eindhoven University of Technology, Eindhoven, The Netherlands

${ }^{c}$ ESB2018 organizing committee member, Dentistry - Regenerative Biomaterials,

Radboudumc \& Radboud Institute for Molecular Life Sciences, Nijmegen, The Netherlands ideas to over 950 participants. The conference followed an inspiring program covering state-of-the-art research and developments in the field via 4 plenary speakers, 230 oral presentations, 700 poster presentations, 4 award sessions, 3 lunch symposia, multiple activities of the Young Scientists' Forum (YSF), and more than 20 industrial exhibitors. Despite the European roots of the ESB, the conference was attended by a large number of participants from other continents, demonstrating the international dimension and collaborative nature of the field.

The conference theme 'Materials for Life' was chosen to express the challenges that the field of biomaterials is facing: to provide effective and affordable biomaterial-based methods to repair and regenerate damaged and diseased tissues and organs. This challenge can only be overcome by converging breakthrough developments from the fields of chemistry, physics, materials science, biology and engineering to address real clinical needs, while also considering the translational pathway from bench to bedside. Advancements in the different disciplines were apparent from the plenary presentations by world renowned leaders in biomaterials science. Confronting conclusions on the value of animal models in anticancer therapy development (by Prof. David Grainger), insights into the role of matrix mechanobiology in cellular and bacterial adhesion (by Prof. Viola Vogel), fundamentals on the role of surfacenanotopographical cues on (stem) cell differentiation and cell metabolomics (by Prof. Matthew Dalby), and translational mechanobiological interplay between matrix and cells toward cardiovascular regeneration (by Prof. Carlijn Bouten) were the topics covered by the plenary speakers, ranging in focus from fundamental mechanistic insights to advanced translational efforts in therapeutic applications. The parallel oral

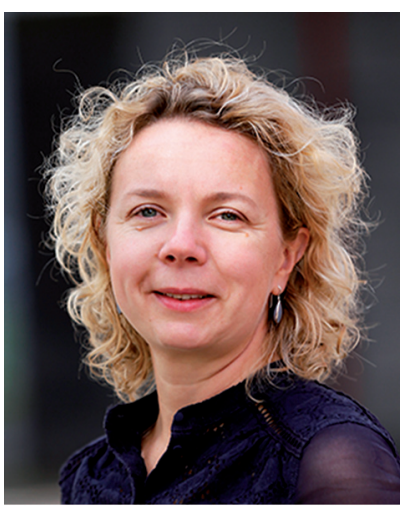

Pamela Habibovic

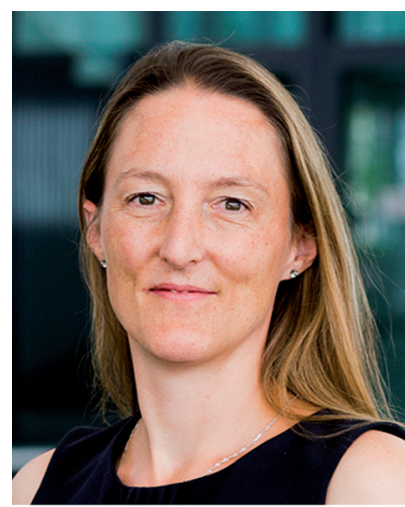

Sandra Hofmann

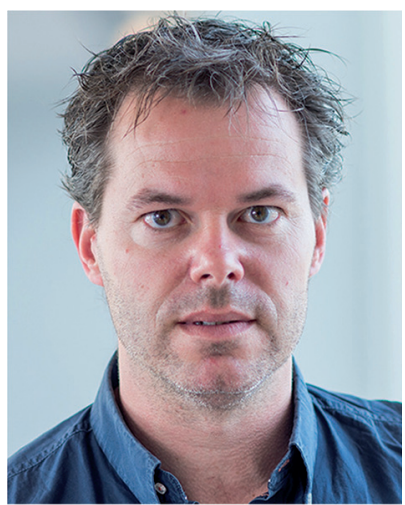

Jeroen van den Beucken 
presentation sessions and poster sessions covered 18 diverse research topics, including 'engineering of tissues and regenerative medicine' and ' $3 \mathrm{D}$ scaffolds' as the most prominent ones, but also novel topics such as 'anti-cancer therapy' and 'computational modeling'.

This themed issue covers a selection of publications that illustrate some of the sparkling, innovative, remarkable and intriguing advances in the field of biomaterials that were presented at ESB2018. It includes, for example, a review by Zadpoor [DOI: 10.1039/ C9BM01247H] on meta-biomaterials describing how architectural design and advanced additive manufacturing can jointly enable the realization of biomaterials with unusual properties. In the paper by Rottmar and co-workers [DOI: 10.1039/C9BM00814D], nicotinic acidloaded three-dimensional silk scaffolds were explored as an immunomodulatory strategy for implantable biomaterials and tissue-engineered constructs. With the same aim, Smits and colleagues [DOI: 10.1039/C9BM01005J] investigated the effect of hemodynamic loading on macrophage polarization, for applications in biomaterial-driven vascular regeneration. In the study by Dankers and co-workers [DOI: 10.1039/ C9BM01241A], co-axial electrospinning of supramolecular polymers based on hydrogen bonding ureido-pyrimidinones was used to develop elastomeric scaffolds with controlled drug release properties. Towards controlled release of multiple growth factors from polymeric implants, Moroni and colleagues [DOI: 10.1039/C9BM00979E] focused on the optimization of a growth factor layer-by-layer assembly technique. Alexander and colleagues [DOI: 10.1039/
C9BM00667B] presented an elegant example of a rapid and facile synthesis route of amphiphilic co-polymers, enabling further functionalization with labels or drugs as well as good control over polymer architecture and selfassembly properties.

This selection of publications from the themed issue highlights both the advancements as well as challenges and opportunities that lie ahead for the field of biomaterials. Teams comprising experts from different disciplines, preferably with clinical and industrial involvement from an early phase of development, need to stay focused on a particular problem in healthcare or the related healthcare industry to translate the available knowledge into successful concepts and eventually products to provide diagnostic and therapeutic opportunities for biomaterials. 